\title{
QUALITY OF WORK LIFE AND EMPLOYEE AFFECTIVE COMMITMENT OF FILLING STATIONS IN RIVERS STATE
}

\author{
${ }^{1}$ Akor John Abah and ${ }^{2}$ Benedict Chima Onuoha, Ph.D \\ ${ }^{1}$ Doctoral student, Department of Management, \\ University of Port Harcourt, \\ Rivers State, Nigeria. \\ Email: johnakor93@gmail.com \\ ${ }^{2}$ Professor of Management, \\ University of Port Harcourt, \\ Rivers State, Nigeria. \\ Email: chimaonuoha2005@yahoo.com
}

\begin{abstract}
One serious issue facing managers of business organization today is to secure employee commitment in the work place. The purpose of this study was to analyze the relationship between 'quality working lifestyle' and employee commitments'. The baseline and organizational theory was the social exchange theory in social structure. The study adopted the cross sectional survey design, with a statistical sample size of 248 employees purposively and randomly selected from eleven (11) filling stations within Port Harcourt metropolis, copies of questionnaire were used as main research instrument or tool to collect data. Data was analyzed using the statistical package for social science (SPSS). The study found that there is a strong positive relationship between "quality of work life" and "employee commitment". Our findings, suggest that companies create enabling environments for them to work effectively to enhance their performance.
\end{abstract}

Key words: Employee, affective commitment. 
Journal DOI: 10.46654/ij.24889849

\subsection{Background to the study}

One serious problem facing today's managers of business organizations is getting employees committed to their job in the work place. To achieve this, which is making employees to be committed to their jobs, the old-fashioned job concept needs to be substituted by 'rich job' concept. The jobs need to be improved in the aspect of technological innovation and individual requirements. The need for improvement of jobs is known as Quality of Work lifestyle. The main perception of this thought would be to address workers as individuals by simply deciding to make the workplace more work-friendly. Based on workers opinions about the quality of their career, assist businesses get basic knowledge of areas that need improvement. It is easy to establish various goals for various companies, but the compelling factor becomes; the effect of duty on the worker, staff involvement in resolving issues and choice making, and a framework which rewards a member of staff for input into the work system.

\section{$2.0 \quad$ Literature Review}

Different meanings and interpretations have been given to the concepts of quality of work life and employee commitment under view. This section of the thesis work is therefore basically concerned with the review of the related literature advanced on the subject matter so far. This section will be split into: empirical studies, conceptual framework and theoretical framework.

\section{Baseline Social and Organizational Theories on Quality of Work Life and Employee Commitment Exchange Theory}

\section{Social Exchange Theory:}

Exchange theorists advanced a fundamental concept of social framework as a setup of societal relationship among personalities (both person and business), where in actuality the relationships entail the trade of respected products (and this can be product, information, symbolical, etc). Exchange concept significantly has called for explicit though societal framework of both product and limitation, usually in the type of systems of social relationships. Thus we will talk about the characteristics and variations in the views on social design associated with main trade theorists in historical development.

\section{Homan Social Structure View}

Homans, (1961) opines that the main function of Social Structure is associated with (sub institutional or elementary) kinds of attitude. Homans designed concept of societal attitude dependent mainly upon personality concepts of research. In his research he established an informative system (1961). Also, he describes this attitude that may be thought as compliance to the regulations of a society (consisting of role-associated attitude). Role-complying conduct ended up being institutionalized attitude, hence main conduct had been described by Homans as sub institutionalized. For Homans, societal structures arise from elementary types of attitude and vary in the long run in reaction to alterations in this attitude.

\section{Blau's View of Social Structure}

Blau's opinion of the concept of social structure is in relation to a reliable micro framework, a component that distinguishes Blau's work from Homans. First, Blau did not establish his concept 
of exchange upon behavioural axioms, instead into their research of unique societal changes. Next, acknowledging that societal frameworks have emergent attributes, he expanded the idea beyond sub phenomena that are institutionalized.

Blau analyzes procedures like group arrangement, integrating of social growth, dispute, and disintergration with regards to concepts of societal changes. However, in his view of different kinds of societal connections developed by trade procedures as time passes comes to constitute quite complicated societal systems (and substructures).

\section{The Concept of Work}

To the Christians, the concept of work means divine punishment for man's original sins. People are involved in different labour activities for man's original sins. As such, profiteering from work was a further sin. The perception of people with regards to work influences that person(s) level of input or the amount of energy they will be willing to expend working. Athenian Greeks was 'work' as labour that was meant only for slaves. As such, works were assigned to salves while things that give leisure, pleasure and status were assigned to high level to citizen, gentlemen and ladies. To another group, 'work' still was labour and hardship that was only undertaken to acquire basic needs of life.

A new thinking was brought to work by the Renaissance and Reformation of the Catholic Churches in the ancient time by making people believe that working meant serving God. In fact, it is argued that "Martin Luther" taught people that working was the will of God, reservation as well as frugality are means of satisfying God and it is also the pathway to redemption. Protestants Reformation summarily saw work as a duty to fulfill one's predestined "calling".

Summarily, some groups of persons see work as divine punishment for the original sins of Adam and Eve. To other group it is seen as labour, hardship and suffering. To some other group, it means fulfilling the divine purpose for creation: i.e. as way of serving God. Others see it as a means of accomplishment.

Cherns and Davis (1975), the originators of the idea of Quality of Working Lifestyle (QWL) in an attempt to define the concept emphasized "the component value of individuals and group autonomy, individual responsibility and interpersonal interdependence in work organization and job designs" (Cherns and Davis, 1975:58). This explanation does not sufficiently touch on the fundamental objectives of QWL which is "well-being" is a construct word defining a psychological state or feelings expressing happiness or satisfaction, as explained by the person's perception.

\section{Perspectives of quality of work life}

Reviews of related literature and analysis have revealed three main perspectives of Quality of work life. These include;

\section{Humanization of work}

Herrick and Maccoby (1975) and Walton (1975) have identified four main principles or features of humanization of work as follows: 


\section{Security}

"Security" for the worker implies freedom from tension and anxiety regarding current and future recruitment, as an illustration, experiencing safe understanding that one is not more likely to get laid-off (Sirgy et al., 2001). All these include the protection, healthcare of employees and security functionality with enhanced physical environment in the work environment, etc. The advocates for the utilization of this particular function in firm claim that putting strategies and implementing systems that ensure employees' safety of health, earnings and both current and upcoming work allow the employee to produce his qualities, ability, talent and ideologies and therefore can be willing to invest his best.

\section{Equity}

Equity concept is a concept that tries to explain relational gratification with regards to impressions of just/unjust distribution of resources with social relations. Although the dimension associated with equity or fairness of rewards is subjective because what satisfies a particular worker may vary from worker to worker.

\section{Individuality}

This is also another integral feature of humanization of work. The application of this concept will inspire employees to recognize and improve on their own ability which will give them (workers) a sense of commitment to the organization and will always put in their best.

\section{Social Integration}

Working is living because man spends the great part of his life working, is an assertion already stated in this research work. Ahiauzu (1999:4) opined that, "when man is at work, he is simultaneously working as well as living his life". There is a relationship between work and the life of the worker, as such the work organization and environment should encourage freedom from prejudice, egalitarianism, inter personal openness, the feeling of community in work organization etc.

\section{Workplace democracy}

Workplace democracy and workers participation are sometimes used interchangeably and at other times distinctively to represent distinct ideological position pertaining to dilemmas of power. Thus, there is no consensus definition of either of these concepts in discourse. The concept refers to freedom and autonomy allowed to workers in deciding their own pace of work. Some of the definitions of workers participation include the ones made by walker (1975) and Clark et al. (1972) as recorded in Ahiaizu A. (1999). Tracking the problem of conceptualizing worker participation with regards to level of involvement, Pateman (1970) discovered three primary kinds of level of involvement such as pseudo involvement, partial involvement and maximum involvement. Pseudo involvement does take place where employees are only offered complete description and insight of measures already taken or about to be taken by administration, aided by aim of persuading employees to consider managerial choices, by producing a perception in employees that their suggestions and needs are concerns to administration. Partial involvement on the other hand takes place where employees can affect choices, nevertheless the final directive rests with administration. Whereas maximum involvement in Pateman's research is the means whereby each separate valued contributor to a 
choice making structure has equivalent capacity to figure out results of choices. Proponents of QWL approach who adopt the workplace Democracy perspective argued that the QWL improves when work is structured around democratic team rather than authoritarian hierarchies.

The principle of democracy implies that workers will no longer see themselves as passive objects but as active players in matters of business. Consequent on these findings therefore, whenever feasible, workers are encouraged to manage themselves.

\subsection{Research Methodology}

According to Ogwo (1900), research methodology is the different ways, method, designs, and system which researchers use in administering and collecting data in research work. This chapter will therefore provide a framework for the procedures and designs, which will be adopted by the researcher in order to attain the objective of the study.

\section{Research Design}

According to Baridam (2001), a research design is the framework or plan that is used as a guide in collecting and analyzing the data for a study.. Basically, there are two types of research design, the experimental and the quasi-experimental design. In the experimental design, all the element of the design are largely under the control of the researcher. In quasi-experimental research design, the various elements of the design are not under the control of the researcher (Baridam, 2001). Thus, the quasi-experiment research design is suitable for studies in administration/ management sciences such as this. In the study, however, the researcher intends to adopt a triangulation of methodologies since no single methodology will adequately give full understanding of human beings. Hence, qualitative and quantitative data will be utilized. Within this frame, the survey research involving cross sectional design was adopted in the study to enable the research gather data from the wider range of subjects since it takes a snapshot at a situation and analyses it. Among other reasons for choosing the survey design are: it is cost and time effective to think about the question. Cross sectional or the survey design is a process whereby standardized information is collected from a representative sample design in such a way that meaningful results were achieved. This study as a quasi-experiment design is correlation and investigates the relationship between quality of work life and employee commitment in Nigeria filling station in River State.

\section{Population of study:}

The population of study consists of all employees in the 16 filling stations located in River State. The Filling Stations are NNPC Mega Station, Total oil station, Mobile oil station, MRS oil station, Abeso oil station, Restopark oil station, South-south Investment, Fort oil station, Mosac filling station, KSB filling station, Chelsea oil, Roman oil, Oando Plc., Stanefield oil, Joras oil and petrol chemical. Since it is not always possible to reach the entire population, the researcher identifies that portion of the population that will be accessed and this population is called target population, which in this case are employees of eleven (11) filling stations in River State. The employees will make the top, middle and lower level category managers in chosen filling stations and such constitute the target population. The choice of the industry was informed by the fact that the filling station sector is one of the most mature section in the Nigerian economy, with 
little government interference. Also, the industry attracts highly skilled employees from across the 36 states of Nigeria.

\begin{tabular}{|l|l|l|l|l|l|}
\hline S/N & Name of organization & Distribution & retrieved & Valid & Invalid \\
\hline 1 & NNPC Mega Station & 25 & 25 & 25 & 0 \\
\hline 2 & RESTOPARK OIL & 25 & 25 & 25 & 0 \\
\hline 3 & ABESCO OIL & 23 & 23 & 21 & 2 \\
\hline 4 & TOTAL OIL & 22 & 22 & 22 & 0 \\
\hline 5 & MOBIL OIL & 23 & 23 & 21 & 2 \\
\hline 6 & FORTE OIL & 25 & 25 & 24 & 1 \\
\hline 7 & MOSAC OIL & 20 & 20 & 20 & 0 \\
\hline 8 & SOUTH- SOUTH OIL & 21 & 21 & 20 & 1 \\
\hline 9 & KSB Filling Station & 20 & 20 & 20 & 0 \\
\hline 10 & CHELSEA OIL & 24 & 24 & 22 & 2 \\
\hline 11 & PETRO-CHEMCAL & 20 & 20 & 20 & 0 \\
\hline & Total & 248 & 248 & 240 & 8 \\
\hline
\end{tabular}

\section{Source: Survey data, 2014}

\section{Sampling Technique and sample size determination}

The researcher purposively chose (11) Filling Stations since it is not always possible to reach the entire population which in this case are employees of eleven (11) filling stations in River State. The filling stations have 3 main units. They are; Resources functions, Revenue function and Corporate Transformation, each with a team as its leader and member. All the team leaders and team members and petroleum resources, it was impossible to reach the entire population. The accessible population in this study was sampled with "questionnaire" as instrument for data collection. Information on employee commitment in these Filling Stations was obtained through personal knowledge of this study, simple random sampling technique and social science (Baridam, 2008).

The sample size for this study was determined by the application of a Taro Yemen's formula. According to Baridam (2001), the formula for determining the sample size is as follows:

$$
\begin{aligned}
& n=\frac{\mathrm{N}}{1+N(e) 2} \text { where } \\
& \mathrm{n}=\text { sample size sought } \\
& \mathrm{e}=\text { level of significance } \\
& \mathrm{N}=\text { population size }
\end{aligned}
$$

In this study, the population was 650 . Thus the sample desired is

$$
=\frac{650}{1+650(0.05) 2}
$$


Journal DOI: 10.46654/ij.24889849

$$
\begin{aligned}
& =\frac{650}{1+650(0.0025)} \\
& =\frac{650}{1+1.625} \\
& =\frac{650}{2.625} \quad=\mathbf{2 4 8}
\end{aligned}
$$

\section{Operational measurement of Variable}

Operational definition of a variable according to Cooper and Schindler (2011) is a definition stated in terms of specific criteria for testing or measurement. These terms must refer to empirical standards (we must be able to count, measure or in some way gather the information through our senses).

Whether the object to be defined is physical or highly abstract, the definition must specify the characteristics and how they are to be observed.

Predictor Variable: Quality of work life is the predictor variable in this study and was measured using two empirical referents which are: job security and work and non-work life balance (Luthans, 1985). A 10 item quality of work life instrument was designed for the study where respondents will grade the responses to reflect their extent of agreement. These questions were measured on a 5 points likert scale ranging from Very High Extent (VHE-5), Great Extent (GE4), Moderate Extent (ME-3), Low Extent (LE-2) and Very Low Extent (VLE-1). These are reflected in the questionnaire attached to this paper.

\section{Criterion/ dependent variable:}

Employee commitment is the criterion in the study and this was measured using the measures of commitment, especially those that are not opt for the study, which are; affective commitment, normative commitment, and continuance commitment. A 10 item employee commitment instrument is used for the study, and the 4point likerts scale is used to ascertain the extent to which respondents agree or disagree with the indicators (Meyer and Allen, 1900). These questions were measured on a 4 point likerts scale ranging from high extent (VEE-4), great extent (GE-3), Low extent (LE-2) and very low extent (VLE-1). These are reflected in the low questionnaire attached to this proposal.

Contextual Variable: Organizational culture is the contextual variable in the study, and function as moderate variable. A five item instrument is used in measurement of organization culture (Amah, 2009) and also measure on likerts scale with same rating above. 


\section{RESULT AND DISCUSSIONS}

\subsection{Data Analysis and Presentation}

Presented in this chapters are the data generated from the field survey through the administration of copies of structured questionnaire and oral interviews. Presented below is the reliability analysis for the study.

Table 4.1 showing reliability for the study.

\begin{tabular}{|l|l|l|}
\hline Variables & No. of items & Cranach Alpha \\
\hline Quality of Work Life & 10 & 0.908 \\
\hline Job security and satisfaction & 5 & 0.744 \\
\hline $\begin{array}{l}\text { Work and Non-work life balance } \\
\begin{array}{l}\text { Pay and benefit satisfactory } \\
\text { Growth and Development } \\
\text { Opportunity satisfaction }\end{array}\end{array}$ & 5 & 0.921 \\
\hline Employee Commitment & 10 & 0.857 \\
\hline Affective Commitment & 5 & 0.795 \\
\hline Organizational Culture & 5 & 0.715 \\
\hline
\end{tabular}

A total of two hundred and forty-eight (248) copies of questionnaire were administered and all of them were returned for analysis after which 240 questionnaires were deemed useful data validation and cleaning process. The study was carried out using a cross-sectional approach of investigation and copies of questionnaires were distributed as a means of generating quantitative data from the target respondents. Presented in table below is the outcome of the field and questionnaires cleaning process.

Table 4.2 illustrating the questionnaires distribution and retrieval frequency

\begin{tabular}{|l|l|l|l|l|}
\hline Questionnaire & $\begin{array}{l}\text { Number } \\
\text { Distributed }\end{array}$ & $\begin{array}{l}\text { Number } \\
\text { Returned }\end{array}$ & $\begin{array}{l}\text { Number used } \\
\text { In Analysis }\end{array}$ & $\begin{array}{l}\text { Number of } \\
\text { Rejects }\end{array}$ \\
\hline Frequency & $248(100 \%)$ & $240(100 \%)$ & $240(96.77 \%)$ & $8(3.23 \%)$ \\
\hline
\end{tabular}

Table 4.2 illustrating the questionnaires distribution and retrieval frequency which indicated that 240 valid responses were obtained out of the 248 questionnaires distributed which represents $96.77 \%$ while 8 copies were found to be invalid representing $3.23 \%$.

\section{Demographic Analysis}

The outcomes for the statistics analysis performed on various properties of the sample are shown in this section. Analysis will be performed on six key traits of the test which consists of title of organization, sex, grouped personnel considering their matrimonial position bothering on unmarried, married, and divorced; matrimonial position; age types, qualification measures; by which workers are categorized predicated on their educational skills and lastly, experience; right here respondents are categorized according to their skills and many years of solution to your business in particular. 
Table 4.3 showing the gender distribution for the study.

GENDER DISTRIBUTION FOR THE RESPONDENTS

\begin{tabular}{|c|r|r|r|r|}
\hline & \multicolumn{1}{|l|}{ Frequency } & \multicolumn{1}{l|}{ Percent } & Valid percent & \multicolumn{2}{l|}{$\begin{array}{l}\text { Cumulative } \\
\text { Percent }\end{array}$} \\
\hline Valid MALE & 102 & 42.5 & 42.5 & 42.5 \\
FEMALE & 138 & 57.7 & 57.7 & 100.0 \\
TOTAL & 240 & 100.0 & 100.0 & \\
\hline
\end{tabular}

\section{GENDER DISTRIBUTION FOR THE RESPONDENTS}

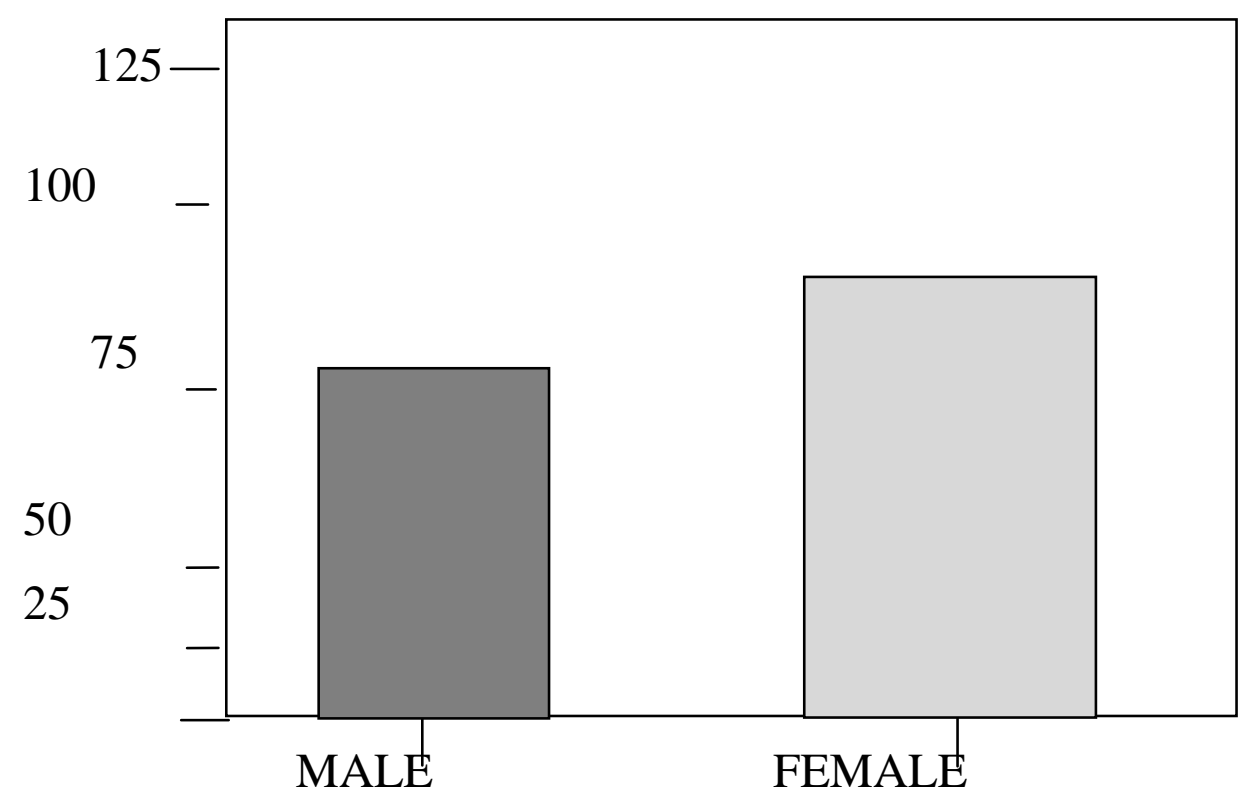

\section{GENDER DISTRIBUTION FOR THE RESPONDENTS}

Fig. 4.1 showing bar chat distribution of the study.

Table 4.3 and fig 4.1 show that for the gender characteristic, the female respondents are at a $57.5 \%$ to $42.5 \%$ difference percentile rate. This goes to imply that most of the respondents who participated in the study were female.

Table 4.4 illustrating the status characteristic of respondents

MARITAL STATUS FOR THE RESPONDENTS

\begin{tabular}{|c|r|r|r|r|}
\hline & Frequency & \multicolumn{1}{|l|}{ Percent } & Valid Percent & \multicolumn{2}{l|}{ Cumulative } \\
& & & & Percent \\
\hline Valid SINGLE & $1 \mathrm{O} 5$ & 43.5 & 43.8 & 43.8 \\
MARRIED & 56.5 & 56.5 & 56.3 & 100.0 \\
TOTAL & 100.0 & 100.0 & 100.0 & \\
\hline
\end{tabular}




\section{MARITAL STATUS OF THE RESPONDENTS}

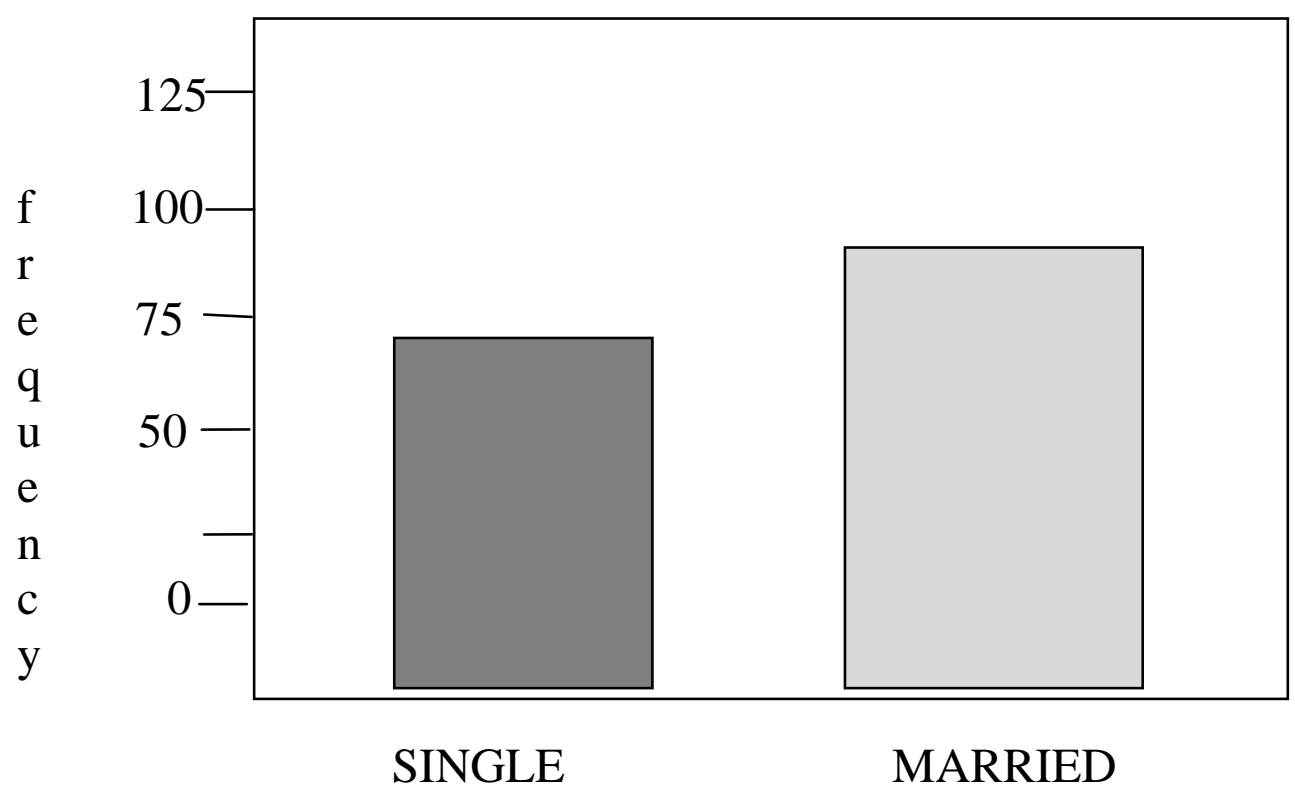

\section{MARITAL STATUS FOR THE RESPONDENTS}

Fig 4.2 showing bar chart distribution for respondents' marital status.

For the marital status of the respondents, table 4.4 and fig 4.2 illustrate that the married category has more respondents at a $56.3 \%$ percentile rate, followed by the single category at a $43.8 \%$ percentile rate and zero response for the separated category.

Table 4.5 Age distribution of respondents

AGE CLASSIFICATION

\begin{tabular}{|c|r|r|r|r|}
\hline & Frequency & Percent & Valid Percent & \multicolumn{2}{l|}{$\begin{array}{l}\text { Cumulative } \\
\text { Percent }\end{array}$} \\
\hline Valid less than 25 Yrs & 63 & 26.3 & 26.3 & 26.3 \\
26-35 Yrs & 128 & 53.3 & 57.5 & 79.6 \\
36-45 Yrs & 34 & 14.2 & 14.2 & 93.8 \\
46-55 Yrs & 9 & 3.8 & 3.8 & 97.5 \\
ABV 55 Yrs & 6 & 2.5 & 2.5 & 100.0 \\
TOTAL & 240 & 100.0 & 100.0 & \\
\hline
\end{tabular}

From the table above, $26.3 \%$ of the respondents are less than 25 Years, $53.3 \%$ of the respondents are between 26-35years. 
AGE CLASSIFICATION

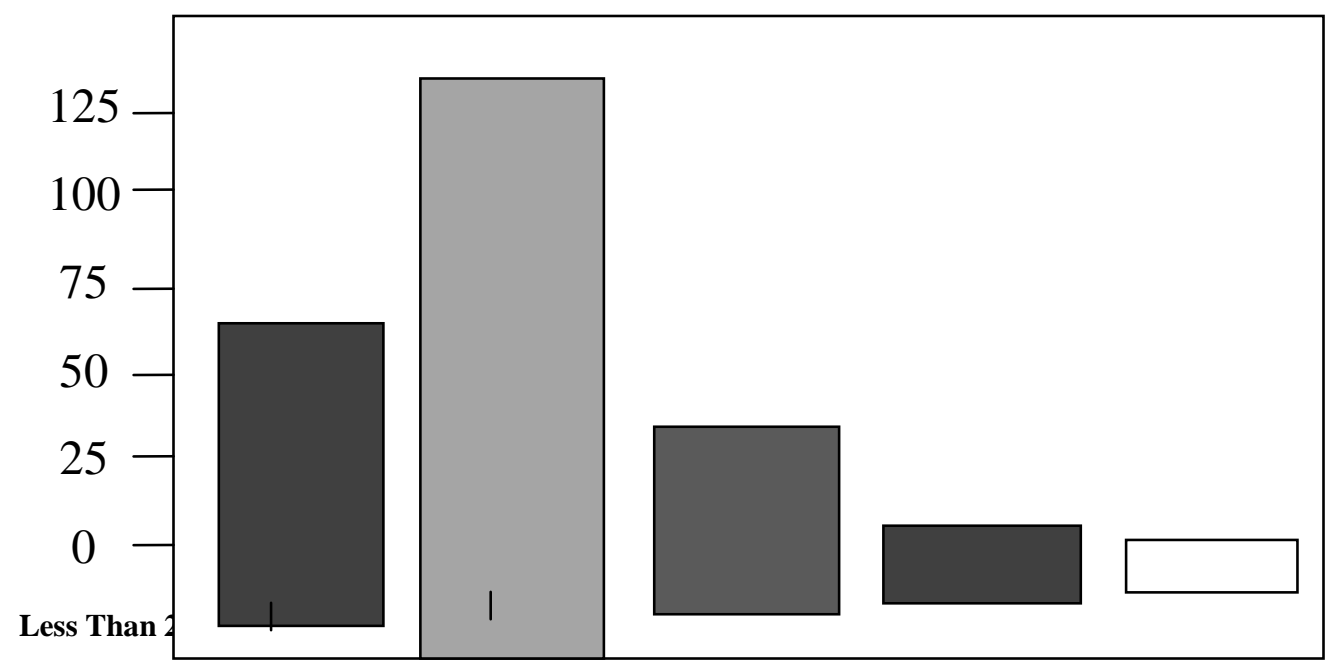

AGE CLASSIFICATION

Fig 4.3 showing the bar chart distribution, the table 4.5 and bar chart 4.3 show that most of the respondents fall into the 26-35 years age bracket at a 53.3\% percentile rate, followed by the less than 25 year age bracket at a $26.3 \%$ percentile rate followed by the $36-45$ years bracket and the 46-55 years and the above 55 years categories having a $3.8 \%$ and $2.5 \%$ percentile rating respectively.

Table 4.6 illustrating the qualification distribution for the respondents QUALIFICATION DISTRIBUTION FOR THE RESPONDENTS

\begin{tabular}{|c|c|c|c|c|}
\hline & Frequency & Percent & Valid Percent & $\begin{array}{l}\text { Cumulative } \\
\text { Percent }\end{array}$ \\
\hline Valid SSCE & 80 & 33.3 & 33.3 & 33.3 \\
\hline OND & 146 & 60.8 & 60.8 & 94.2 \\
\hline B .Sc. & 14 & 5.8 & 5.8 & 100.0 \\
\hline TOTAL & 240 & 100.0 & 100.0 & \\
\hline
\end{tabular}




\section{QUALIFICATION DISTRIBUTION FOR THE RESPONDENTS}

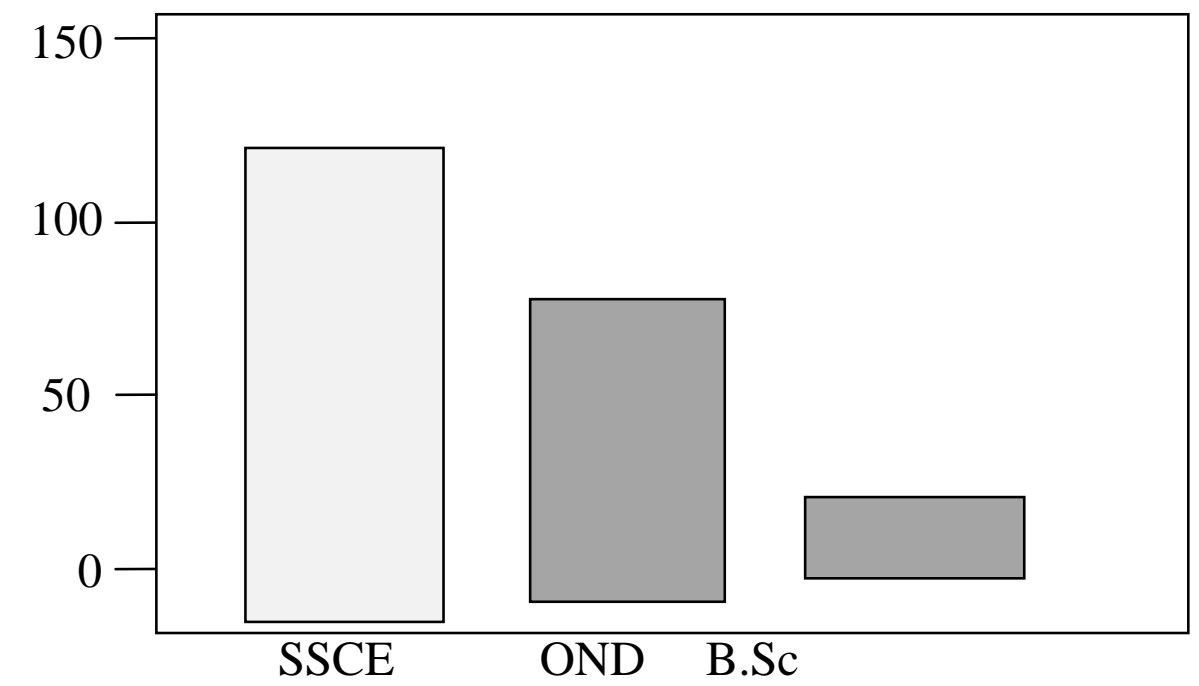

\section{QUALIFICATION DISTRIBUTION FOR THE RESPONDENTS}

Fig 4.4 showing the bar chart for qualification.Table 4.6 and figure 4.4 show that most of the respondents under the qualification characteristics of the sample have obtained SSCE at a percentage of $60.83 \%$ followed by those who have obtained diploma certificates at a $33.337 \%$ percentile rate, and those with BSc degrees at $5.84 \%$ and none of those with MSc degrees.

Table 4.7: FILLING STATION WORKERS EXPERIENCE

\begin{tabular}{|c|r|r|r|r|}
\hline & Frequency & Percent & Valid Percent & Cumulative Percent \\
\hline Valid 5 YRS & 167 & 27.9 & 27.9 & 27.9 \\
5-10 YRS & 147 & 61.3 & 61.3 & 89.2 \\
$11-15$ YRS & 19 & 7.9 & 7.9 & 97.1 \\
16-20 YRS & 7 & 2.9 & 2.9 & 100.0 \\
TOTAL & 240 & 100.0 & 100.0 & \\
& & & & \\
& & & & \\
& & & & \\
\end{tabular}




\section{FILLING STATION WORKERS EXPERIENCE}

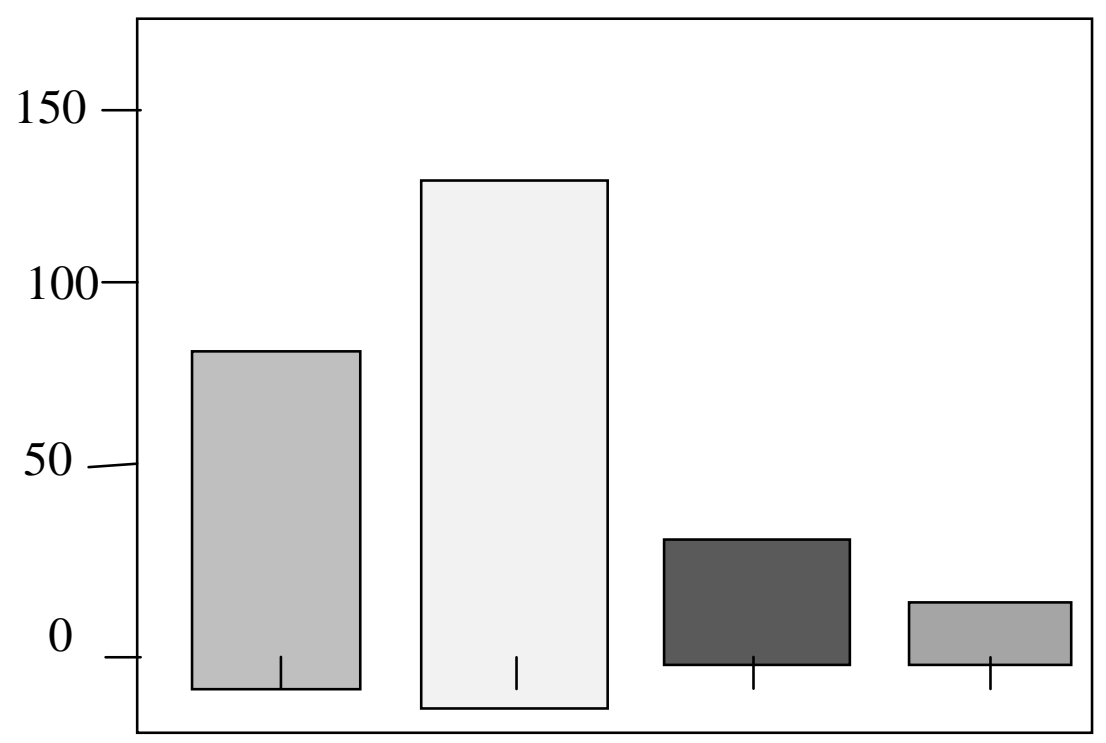

\section{YRS 5-10YRS 11-15YRS 16-20YRS}

\section{FILLING STATION WORKERS EXPERIENCE}

Fig 4.5 showing Bar chart distribution for respondents' experience.

The table 4.7 and fig. 4.5 above illustrate the tenure characteristic of the respondents with a majority of the respondents having served with their particular and respective organization between 5 - 10 years, making up for $63.3 \%$ percentile rate, followed by those with less 5 years' experience accounting for $27.9 \%$ of the total number of respondents.

This is followed by the $11-15$ and $16-20$ years categories with a percentile rate of $7.9 \%$ and $2.9 \%$ respectively. 
International Journal of Advanced Academic Research (Social and Management Sciences) | ISSN: 2488-9849

Vol. 6, Issue 11 (November, 2020) | www.ijaar.org

Journal DOI: 10.46654/ij.24889849

Article DOI: 10.46654/ij.24889849.s61121

Table 4.8: List of Filling Stations Studied

Name of Institutions

\begin{tabular}{|c|c|c|c|c|c|}
\hline & & Frequency & Percent & Valid Percent & Cumulative Percent \\
\hline \multirow{12}{*}{ 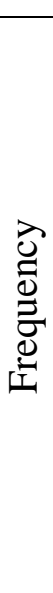 } & Valid & 25 & 10.4 & 10.4 & 10.4 \\
\hline & & 25 & 10.4 & 10.4 & 20.8 \\
\hline & & 21 & 8.8 & 8.8 & 29.6 \\
\hline & & 22 & 9.2 & 9.2 & 38.8 \\
\hline & & 21 & 8.8 & 8.8 & 47.5 \\
\hline & & 24 & 10.0 & 10.0 & 57.5 \\
\hline & & 20 & 8.3 & 8.3 & 65.8 \\
\hline & & 20 & 8.3 & 8.3 & 74.2 \\
\hline & & 20 & 8.3 & 8.3 & 82.5 \\
\hline & & 22 & 9.2 & 9.2 & 91.7 \\
\hline & & 20 & 8.3 & 8.3 & 100.0 \\
\hline & TOTAL & 240 & 100.0 & 100.0 & \\
\hline
\end{tabular}

Filling Stations

NNPC Mega
Total Oil
Mobil Oil
Abesco Oil
Restopark
South South
Investment
Forte Oil
Mosac Fuelling
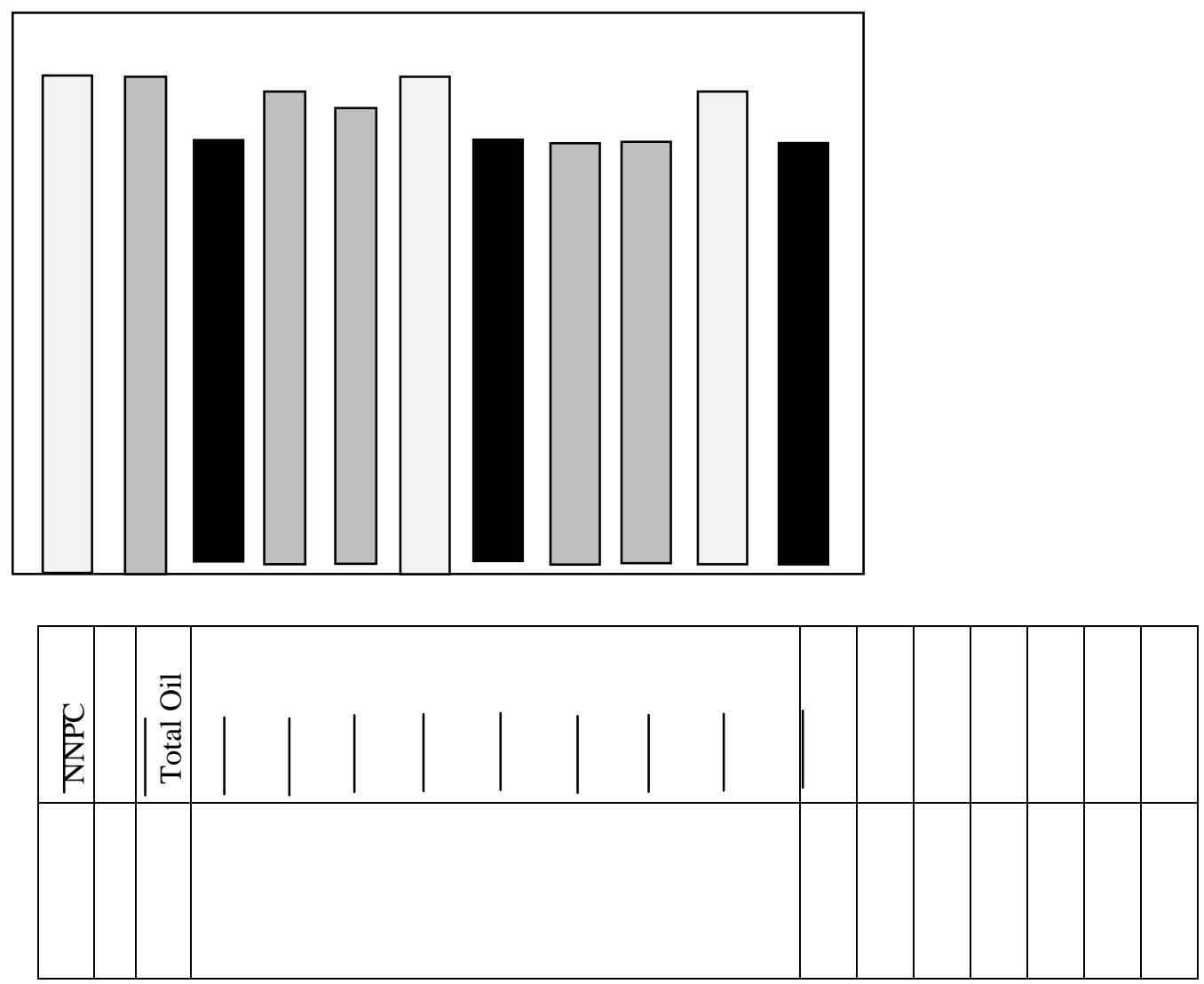

Name of Fuelling Stations

Fig. 4.6 showing bar chart distribution for the filling stations studied. 


\section{Unvariete Analysis}

For the univariate analysis, descriptive statistics is performed on specific factors and their procedures. The predictor variable which is quality of work life carries the following empirical referents: job security, work and non-work life balance; while the criterion variable which is employee commitment is measured by affective commitment and normative commitment. These questions were measured on a 5-point likert scale ranging from Very High Extent (VHE-5), Great Extent (GE-4), Moderate Extent (ME-3), Low Extent (LE-2) and Very Low Extent (VLE1). These are reflected in the questionnaire attached to this paper.

Table 4.9 illustrates the descriptive statistics for security.

PREDICTOR: Quality of Work Life

\begin{tabular}{|l|r|r|r|}
\hline Job security & N & Mean & Std Deviation \\
\hline & statistics & statistics & statistics \\
\hline $\begin{array}{l}\text { To what extent does your filling station plan } \\
\text { for and implement long term goals for its } \\
\text { staff? }\end{array}$ & 240 & 3.02 & 0.996 \\
\hline $\begin{array}{l}\text { To what extent is there room for growth and } \\
\text { development in your filling station? }\end{array}$ & 240 & 2.93 & 1.194 \\
\hline $\begin{array}{l}\text { To what extent are decisions concerning } \\
\text { staff roles and expectations well } \\
\text { communicated? }\end{array}$ & 240 & 3.12 & 1.211 \\
\hline $\begin{array}{l}\text { To what extent do you trust in the skill and } \\
\text { expertise of your filling station management } \\
\text { staff? }\end{array}$ & 240 & 3.52 & 0.985 \\
\hline $\begin{array}{l}\text { To what extent are employees well regarded } \\
\text { and actions regarding them thoroughly } \\
\text { considered in your filling station? }\end{array}$ & 240 & 3.00 & 1.168 \\
\hline
\end{tabular}




\begin{tabular}{|l|l|l|l|l|l|l|}
\hline Job security & \multicolumn{5}{|c|}{ FREQUENCY } \\
\hline & (VLE) & (LE) & (ME) & (GE) & (VHE) \\
\hline $\begin{array}{l}\text { To what extent does your filling station plan } \\
\text { for and implement long term goals for its } \\
\text { staff? }\end{array}$ & 14 & 67 & 66 & 86 & 7 \\
\hline $\begin{array}{l}\text { To what extent is there room for growth and } \\
\text { development in your filling station? }\end{array}$ & 21 & 88 & 48 & 54 & 29 \\
\hline $\begin{array}{l}\text { To what extent are decisions concerning } \\
\text { staff roles and expectations well } \\
\text { communicated? }\end{array}$ & 26 & 50 & 69 & 60 & 35 \\
\hline $\begin{array}{l}\text { To what extent do you trust in the skill and } \\
\text { expertise of your filling station management } \\
\text { staff? }\end{array}$ & 6 & 32 & 70 & 96 & 36 \\
\hline $\begin{array}{l}\text { To what extent are employees well regarded } \\
\text { and actions regarding them thoroughly } \\
\text { considered in your filling station? }\end{array}$ & 26 & 57 & 76 & 53 & 28 \\
\hline
\end{tabular}

\begin{tabular}{|l|l|l|l|l|l|}
\hline Job security & \multicolumn{5}{|c|}{ VALID PERCENT } \\
\hline $\begin{array}{l}\text { To what extent does your filling station plan } \\
\text { for and implement long term goals for its } \\
\text { staff? }\end{array}$ & 5.8 & 27.9 & 27.5 & 35.8 & 2.9 \\
\hline $\begin{array}{l}\text { To what extent is there room for growth and } \\
\text { development in your filling station? }\end{array}$ & 8.8 & 36.7 & 20 & 22.5 & 12.1 \\
\hline $\begin{array}{l}\text { To what extent are decisions concerning } \\
\text { staff roles and expectations well } \\
\text { communicated? }\end{array}$ & 10.8 & 20.8 & 28.8 & 25 & 14.6 \\
\hline $\begin{array}{l}\text { To what extent do you trust in the skill and } \\
\text { expertise of your filling station management } \\
\text { staff? }\end{array}$ & 2.5 & 13.3 & 29.2 & 40.0 & 15.0 \\
\hline $\begin{array}{l}\text { To what extent are employees well regarded } \\
\text { and actions regarding them thoroughly } \\
\text { considered in your filling station? }\end{array}$ & 10.8 & 23.8 & 31.7 & 22.1 & 11.7 \\
\hline
\end{tabular}

The table above gives a summary of the descriptive statistics on the 5 - item indicators of job security which is a measure of the independent variable, quality of work life (see table 4.9AA$\mathrm{AF}$ and figs 4.7-4.11). Mean average score and standard deviation average scores from the table above is 3.118 and 1.1108 respectively.

These means of all questions on job security range between $2.93-3.52$. These means are high and indicate a high tendency for the agreement that the employees of filling stations are concerned about job security.

Table 4.10 illustrating the descriptive statistics for work and non-work life. 


\begin{tabular}{|l|l|l|l|}
\cline { 2 - 4 } \multicolumn{1}{l|}{} & \multicolumn{3}{l|}{ PREDICTOR: Quality of Work life } \\
\hline & N & Mean & Std. Deviation \\
\hline Work and Non-work life balance & Statistic & Statistic & Statistic \\
\hline $\begin{array}{l}\text { To what extent do you enjoy your } \\
\text { work and hardly find it boring or } \\
\text { tedious? }\end{array}$ & $\mathbf{2 4 0}$ & $\mathbf{3 . 1 5}$ & $\mathbf{1 . 1 1 4}$ \\
\hline $\begin{array}{l}\text { To what extent are employees in } \\
\text { your filling station allowed to go on } \\
\text { leave when necessary? }\end{array}$ & $\mathbf{2 4 0}$ & $\mathbf{3 . 1 5}$ & $\mathbf{1 . 1 1 4}$ \\
\hline $\begin{array}{l}\text { To what extent do you think or } \\
\text { worry about work (in the negative) } \\
\text { when you are not actually at work or } \\
\text { travelling to work? }\end{array}$ & $\mathbf{2 4 0}$ & $\mathbf{2 . 9 3}$ & $\mathbf{1 . 1 1 4}$ \\
\hline $\begin{array}{l}\text { To what extent do you miss out } \\
\text { quality time with your family or } \\
\text { friends because of pressure of work? }\end{array}$ & $\mathbf{2 4 0}$ & $\mathbf{2 . 9 3}$ & $\mathbf{1 . 1 1 4}$ \\
\hline $\begin{array}{l}\text { To what extent do you differentiate } \\
\text { work related issues from family } \\
\text { related issues? }\end{array}$ & $\mathbf{2 4 0}$ & $\mathbf{3 . 1 5}$ & $\mathbf{1 . 1 1 4}$ \\
\hline
\end{tabular}

\begin{tabular}{|l|l|l|l|l|l|}
\cline { 2 - 6 } \multicolumn{1}{c|}{} & \multicolumn{5}{c|}{ FREQUENCY } \\
\hline Work and Non-work life balance & $\begin{array}{l}\text { VERY } \\
\text { LOW } \\
\text { EXTENT } \\
\text { (VLE) }\end{array}$ & $\begin{array}{l}\text { LOW } \\
\text { EXTENT } \\
\text { (LE) }\end{array}$ & $\begin{array}{l}\text { MODERATE } \\
\text { EXTENT } \\
\text { (ME) }\end{array}$ & $\begin{array}{l}\text { GREAT } \\
\text { EXTENT } \\
\text { (GE) }\end{array}$ & $\begin{array}{l}\text { VERY HIGH } \\
\text { EXTENT (VHE) }\end{array}$ \\
\hline $\begin{array}{l}\text { To what extent do you enjoy your } \\
\text { work and hardly find it boring or } \\
\text { tedious? }\end{array}$ & $\mathbf{2 1}$ & $\mathbf{4 9}$ & $\mathbf{6 4}$ & $\mathbf{8 5}$ & $\mathbf{2 1}$ \\
\hline $\begin{array}{l}\text { To what extent are employees in your } \\
\text { filling station allowed to go on leave } \\
\text { when necessary? }\end{array}$ & $\mathbf{2 1}$ & $\mathbf{4 9}$ & $\mathbf{6 4}$ & $\mathbf{8 5}$ & $\mathbf{2 1}$ \\
\hline $\begin{array}{l}\text { To what extent do you think or worry } \\
\text { about work (in the negative) when you } \\
\text { are not actually at work or travelling } \\
\text { to work? }\end{array}$ & $\mathbf{2 1}$ & $\mathbf{8 8}$ & $\mathbf{4 8}$ & $\mathbf{5 4}$ & $\mathbf{2 9}$ \\
\hline $\begin{array}{l}\text { To what extent do you miss out } \\
\text { quality time with your family or } \\
\text { friends because of pressure of work? }\end{array}$ & $\mathbf{2 4 0}$ & $\mathbf{8 8}$ & $\mathbf{4 8}$ & $\mathbf{5 4}$ & $\mathbf{2 9}$ \\
\hline $\begin{array}{l}\text { To what extent do you differentiate } \\
\text { work related issues from family } \\
\text { related issues? }\end{array}$ & $\mathbf{2 1}$ & $\mathbf{4 9}$ & $\mathbf{6 4}$ & $\mathbf{8 5}$ & $\mathbf{2 1}$ \\
\hline
\end{tabular}




\begin{tabular}{|c|c|c|c|c|c|}
\hline Work and Non-work life balance & \multicolumn{4}{|c|}{ VALID PERCENT } & \multirow{2}{*}{$\begin{array}{l} \\
8.8 \\
\end{array}$} \\
\hline $\begin{array}{l}\text { To what extent do you enjoy your } \\
\text { work and hardly find it boring or } \\
\text { tedious? }\end{array}$ & 8.80 & 20.4 & 26.7 & 35.4 & \\
\hline $\begin{array}{l}\text { To what extent are employees in your } \\
\text { filling station allowed to go on leave } \\
\text { when necessary? }\end{array}$ & 8.8 & 20.40 & 26.7 & 35.4 & 8.8 \\
\hline $\begin{array}{l}\text { To what extent do you think or worry } \\
\text { about work (in the negative) when you } \\
\text { are not actually at work or travelling } \\
\text { to work? }\end{array}$ & 8.8 & 36.7 & 20 & 22.5 & 12.1 \\
\hline $\begin{array}{l}\text { To what extent do you miss out } \\
\text { quality time with your family or } \\
\text { friends because of pressure of work? }\end{array}$ & 8.8 & 36.7 & 20.0 & 22.5 & 12.1 \\
\hline $\begin{array}{l}\text { To what extent do you differentiate } \\
\text { work related issues from family } \\
\text { related issues? }\end{array}$ & 8.8 & 20.4 & 26.7 & 35.4 & 8.8 \\
\hline
\end{tabular}

The table gives a summary of descriptive statistics on the 5- item indicator of work and nonwork-life which is a measure of the independent variable, quality of work (see tables 4.12 AGAL and Figs 4.12-4.16). Mean average scores and standard deviation average scores from the table above is 3.062 and 1.13 respectively. The means of all the facets of job security range between 2.93-3.15 indicate a high tendency. It can be deduced that employees of filling station are concern about their work and non-work-life balance.

\subsection{SUMMARY}

\section{CONCLUSION}

The intent of this study was the empirical investigation into the relationship between quality of work life and employee affective commitment. Analysis was carried out at the individual level within the target organization. Findings revealed significant correlation between both variables as both variables strongly correlate and show significant association. The findings also revealed organization culture as a partial moderator in the relationship. Based on these findings, we therefore conclude that in order to fully utilize the productive capacity of the employee through increased commitment levels, effort should be made in ensuring a more balanced work-life quality for employees.

The effective management of an employee's perceived sense of job security is a necessary ingredient in improving employee commitment levels.

To effectively enhance the association of quality of work life and employee commitment, related activities should be embedded in the culture of the organization. 


\section{RECOMMENDATIONS}

In view of the research on the importance or quality of work life in improving employee commitment, the following recommendations are herein postulated:

1. Policies on the management of the employees' work schedules should be made to allow for leisure and family issues.

2. The organization atmosphere should be structured by management in such a way that appreciates and recognizes employees for their efforts, contribution as well as prevailing difference both at the individual and at the organization levels.

3. More should be done by management as regards workplace relations and team orientations in order to further enhance the quality of work life.

4. A supportive working environment that allows participatory approach to issues regarding employees will ultimately improve the normative and effective commitment among employees.

5. Welfare packages, training, regular annual vacation, counseling services, to give assurance and also make employees see the benefit of staying behind when compared with the cost of leaving.

\section{Contribution to knowledge}

An extensive influence of moderating variables on workplace like job security, work and nonwork life balance, pay and benefit satisfaction and growth and development opportunities satisfaction in attracting commitment of employees has been sharpened through this study.

\section{Suggestions for further studies}

This research work is not exhaustive as a result of various limitation and time related factors. There is still room for further research. Further research is hereby suggested in other related and equally important areas such as other dimensions of quality of work life in relations to employee commitment. Studies can also be carried out in other sectors and industries which could also serve as a point of departure for the studies. 


\section{REFERENCES}

Ahiauzu, A. (1999). The African industrial man. Port Harcourt: CIMRAT Pub lications

Adams, J. (1963). Toward an understanding of inequality. Journal of Abnormal and social psychology, 67 (5): 422-436.

Allen, N. and Meyer, J. (1990). The Measurement and antecedents of affective, continuance, and normative commitment to the organization. In journal of occupational psychology, 6, (1) $1-18$

Amah, E. (2010). Human Resources Management. Port Harcourt: Amethyst \&colleagues publishers.

Andrews, F, and Withey, s. (1975). Social indicators of well-being Americans' precption of life quantity. New York. Plenium press.

Arabic S. (2000). Strategies, plans And guidelines to achieve job Security. Management Study. Q., P. 37

Argyris, S. (1987). Personality and organization: The conflict between system and individual. New York: Garland Publisher, Inc.

Asika, n. (2001). Research method in behavioral sciences. Lagos Longman Nig. Pls

Bateman, T. and Organ, D.W. (1983). Job satisfaction and the good soldier: The relationship between affect and employee citizenship' academy of management journal, 26(3), 587593.

Baridam, D. and Nwebere, B. (2008). Understanding and managing organizational behavior. Port Harcourt: Sherbook publishers.

Birdam, D . (2001). Research method in administrative sciences. Port Harcourt: Sherbrook Asociates.

Blau, P (1964). Exchange and ampbell, A. (1981). The es sence of well-being in America: Recent patterns and trends. New York: McCraw-Hill.

Chelte, A. (1983). Organizational commitment, job satisfaction and quality of work life. U.M.I Dissertation Information Service.

Cherns, A. (1975). Perspective on the quality of work life. In journal or Occupational Psychology, 48:155-167 cohen, L. Manion, L and Mornsol, K.(2007). Research Methods in Education. New York: Rutledge Publishers 
International Journal of Advanced Academic Research (Social and Management Sciences) | ISSN: 2488-9849 Vol. 6, Issue 11 (November, 2020) | www.ijaar.org

Journal DOI: 10.46654/ij.24889849

Article DOI: 10.46654/ij.24889849.s61121

Cohen, J. and Cohen P. (1983). Applied MULTIPLE REGRESSION/Correlation analysis for the behavioral sciences ( $2^{\text {nd }}$ ed.). New Jersey: Lawrence Erlbaum Associates, Publishers.

Copper, R. (and Schindler, S (2001). Business research methods. New York: McGRAW-Hill 